\title{
Pedagogy and new power relationships
}

\author{
Debbie Holley, \\ Business School, University of North London, \\ 236-250 Holloway Road, London, N7 6PP \\ d.holley@unl.ac.uk \\ Martin Oliver, \\ Higher Education Research and Development Unit, \\ University College London, \\ 1-19 Torrington Place, London, WC1E 6BT \\ martin.oliver@ucl.ac.uk
}

\begin{abstract}
Changes in the context of Higher Education have led to lecturers being disenfranchised. Both the introduction of new managerialism and developments in pedagogy have contributed to this process. On the one hand, performance management and the introduction of teaching and learning strategies have put issues of pedagogy and curriculum development into the realms of strategic management. On the other, student-centred learning has usurped teacher-centred models of education. In this paper, reviews of both of these trends are presented. Based on these, a benchmarking tool has been developed which enables the identification and monitoring of the way that the locus of control for various teaching-related activities has changed. This tool is then applied to the case of an MBA course that was transformed from a traditional to a distance format. The issues that arise from this case are discussed, and conclusions are drawn about the potential implications of "creeping managerialism" in the context of Higher Education.
\end{abstract}

\section{Introduction}

Recent changes in Higher Education have led to the development of a system that can be argued to be more responsive to students' needs. This process has involved increased managerial involvement in issues of pedagogy and curriculum design, and increasingly student-centred strategies for learning and teaching. In this context, the widespread introduction of Learning Technology such as the World Wide Web has acted as a catalyst, accelerating this process of change still further.

In this paper, the trends that have contributed to this process are reviewed. The body of the paper then considers the implications of these developments. A benchmarking tool is developed that allows the impact of these changes to be analysed, and this is applied to an illustrative case. Based on this analysis, conclusions are drawn that point to the long-term implications of these trends. Central to these considerations is the realisation that, in order to empower one group, another must be disempowered.

\section{Background}

In order to understand the changes in power relationships between management, lecturers and students, several factors need to be considered. These include changes in management and in the pedagogic models prevalent in Higher Education. In this section, each of these is considered in turn.

\section{The rise of new managerialism}

In 1979, Margaret Thatcher and the Conservative party were swept into power on an election slogan of 'rolling back the frontiers of state'. The economy was to be transformed, and the policies forged were arguably successful in addressing Britain's problems of inflation and deteriorating international competitiveness. By the late 1980 s, it seemed that a programme of deregulation, privatisation and tax cuts had indeed transformed the economy. The reduction of public spending complimented Thatcher's attachment to free markets, greater choice and rampant individualism (Hutton, 1995). These policies were to change the top-down, monolithic organisations of the Keynesian welfare state and alter the nature of public sector 
management. In parallel, there was a trend toward the decentralisation of health, education and housing. Simultaneously, certain important areas, such as regional policy making and the role of the Metropolitan Boroughs, were centralised. Pollitt et al. (1998) explain that it is perfectly possible to decentralise or devolve authority over certain issues while simultaneously centralising authority over other issues. This led to the the paradox that, whilst extensive decentralisation took place, it appears that from the 1980s and 1990s the UK State became one of the most centralised states in Europe.

In order to achieve the outcomes desired by the government, such as a free economy and 'value for money', the introduction of managerialism within the public sector became a central strategy. This represented a movement away from traditional bureaucratic paternalism (Pollitt, 1990). Two varieties of managerialism have been identified. The first is described as Neo-Taylorism, which focuses on obtaining more for less. The second, the excellence school, derives from the work of Peters (1989). This combines quality, corporate commitment, closeness to the customer and entrepreneurialism. Evidence that managerialism was on the increase can be seen in examples of the National Health Service (NHS), Socially Rented Housing and Secondary Schools (Pollitt, 1993). For Pollitt, managerialism meant that overall control by managers was both necessary and desirable.

Rather than regarding the two strands as separate, Newman and Clarke (1994) suggest that these two varieties of managerialism should be seen as integrated, and show how new managerialism stresses the "right to manage". This reflected other changes in the public sector initiated by the government, such as concern about the economic costs of welfare, a dependency culture, and the power of bureaucrats and professionals. Arguably, the last of these was, the authors argue, the government's main concern. 'Arrogant' professionals were arraigned alongside 'inflexible' bureaucrats and 'interfering' (local) politicians, all of whom had prevented efficient, effective and economic public services. They argued that the only way to disentangle and defuse these 'interlocking modes of power' was by the combination of markets and management.

A further critical approach to new managerialism can be found in the work of Exworthy \& Halford (1999), who review literature about professionals and new managerialism in the public sector. For these writers, capitalism is conceptualised as a dynamic process, and a knock-on effect of the inherently boom-bust nature of capitalist economies is identified as the fiscal crisis in the welfare state. As workers earnings slump, the demand for state services increases, yet at the same time the state is less able to meet demands because taxation income is falling. Such processes are not party-specific; New Labour policies reflect those of the outgoing Conservative administration, for example, in that raising the tax burden is seen as unacceptable. The authors argue that the state still has to fulfil its contradictory role of support for and legitimisation of capitalism, but that new ways have to be found to achieve these desires. It is here that emergent forms of managerialism, with all its implications for the content and organisation of professional work, becomes important. The authors examine conflict, compromise and collaboration, and conclude that relationships between professionals and managers are constituted unevenly between and within different organisations. Social work, health care and primary schools are examined, as is a cross section of professionals 'in a managerial role' across the public sector.

Thus it can be seen that existing research focuses on quite different dimensions of the professionalmanagerial relationship. Exworthy \& Halford suggest this contradiction is rarely acknowledged. In order to draw such relationships together, they present them in the form of a three stage analytical model (Figure 1). This model incorporates first the individual outcome(s) of professional-managerial interactions, which the authors argue will vary between and even within individual professions and managers. The individual dimension of analysis will reflect issues of changing identity, as well as job titles, tasks and career paths. The second dimension is concerned with institutional and organisational dimensions of social groupings around managerialism and professionalism. It has as its emphasis the social capital underpinning the coherence and cohesiveness of both groups. The final dimension is the abstract, which examines conceptual and ideological efforts to define 'professionalism' and 'managerialism'.

This model will prove particularly useful in the context of this paper, since the relationship between 'individual' and 'collectivist' approaches is central to the shift in power that has resulted from the introduction of new managerialism. 


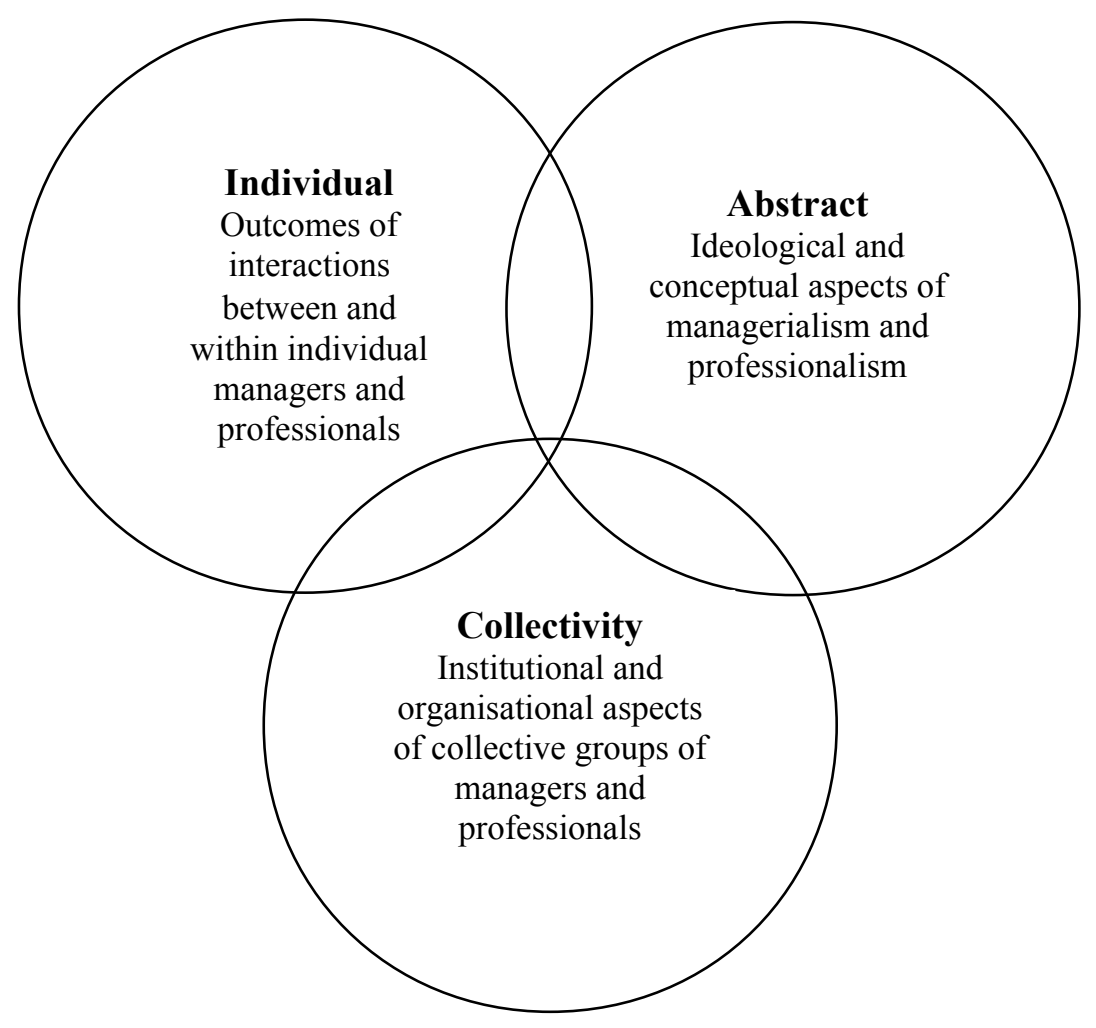

Figure 1: a three-stage analytical model of professional-managerial interactions

\section{The implications of new managerialism for Higher Education}

The introduction of new managerialism to academia is now well established. As a paradigm, its adoption seems a rational solution to calls for greater efficiency and public accountability. In particular, it has led to the increased use of performance management as a tool for setting and monitoring goals. This approach is often simplified to the phrase, "what gets measured gets done", and whilst this is a simplification it does capture the dynamic, objective and transparent philosophy of the paradigm. However, new managerialism remains problematic: it is frequently attacked through the corollary of the simplification, which is that what does not get measured gets neglected (Blalock, 1999).

This is particularly important given the complex nature of education, and the argument that many measures are superficial and over-simplistic. The choice of measures to be employed is often made by management (or at the least, passed on from funding councils via management). This has left some lecturers feeling that the most important elements of their work must now be neglected in order to demonstrate that less important (but more visible) measures have been met.

However, in spite of such developments, it can be argued that Higher Education has maintained a degree of academic autonomy, particularly when compared to the centralist thrust that has been described in schools (Fergusson, 1994). This can be seen, for example, in the establishment of a National Curriculum and national systems of testing which were intended to guarantee minimum standards, consistency and comparability. However, the use of central funding to promote a competitive and expansionist market in Further and Higher Education radically altered the culture of management in many institutions. This so-called agenda of "modernisation" for higher education could be seen in turn as being part of a wider debate around performance and quality. Performance indicators provided management with both a technology and a "rational" justification for exerting increased bureaucratic control (Kirkpatrick \& Lucio, 1995).

Nonetheless, it has become clear that managerial power to define the content and operational goals of professional work has been increased (Hoggett, 1991). For example, policy makers have argued that Universities had, in effect, become playgrounds for self indulgent and inward looking cliques rather than 
engine rooms for a post-industrial economy. Consequently, there was a greater formalisation of tasks and routines, the specialisation of roles and increasing hierarchy, more standardisation and simplification of tasks, and clearer and more objective target setting.

\section{The strategic management of pedagogy}

Further governmental policies that were intended to enhance the quality of Higher Education have added to the process of centralisation described above. In particular, pedagogy, once purely the concern of the academics directly involved in course delivery, has now become an issue for strategy. The Higher Education Funding Council for England (HEFCE) has linked elements of University funding to the creation and implementation of teaching and learning strategies. The consequence of this is that, in many institutions, pedagogy has been placed in the hands of strategic management for the first time.

In line with the other trends towards centralisation described above, the establishment of such strategies seems likely to promote conformity in order to establish common standards. Moreover, the choice of pedagogic approach has become a matter of strategy rather than tactics. In order to recruit non-traditional students (a priority, given HEFCE's access funding and the importance of new student markets), approaches with vocational relevance such as situated learning and problem-based learning are being emphasised.

The implication of this development is that pedagogy, which previous represented an important tactic for lecturers attempting to cope with increasing student numbers, is being taken out of their control. Although some degree of latitude does remain, the choice of teaching techniques is becoming constrained by the decisions of senior management. This particular issue is developed below.

\section{The development of pedagogy}

Traditionally, lecturers have enjoyed considerable autonomy in terms of their approach to teaching, with pedagogy being viewed as part of the remit of domain experts. However, as noted above, recent years have seen a marked increase in participation in H.E., resulting from ongoing governmental intervention (Daniel, 1998). In addition to the introduction of teaching and learning strategies, the government has sought to justify its policies with pedagogic recommendations for Universities. For example, with increased participation combined with a steadily falling unit of resource, lecturers have had to adopt new pedagogical approaches in order to maintain the quality of their courses, such as resource-based learning (Dearing, 1997). Such changes are most clearly visible in the ongoing erosion of individual or small group teaching, and in attempts to change the nature of contact time away from the delivery of information and towards more active participation.

However, changes in pedagogy are nothing new. From the 1960's onwards, Behaviourist psychology sought to place traditional didactic teaching techniques into a more scientific framework (Skinner, 1950). The approach had considerable impact, particularly through the Instructional Design movement in America (e.g. Gagné, 1977). However, recent years have seen a marked reaction against Behaviourism, turning instead towards Constructivist principles and techniques (e.g. Mayer, 1996). In particular, the advent of communication and information technologies has proved to be a significant catalyst for the adoption of Social Constructivism as a guiding principle for Higher Education (e.g. Laurillard, 1993). Inherent in such approaches is the change in role for the lecturer, from "the sage on the stage" to the "guide on the side" (Harasim et al., 1995).

What is new, however, is the change in the locus of control for this evolutionary process. Whilst earlier developments were driven by educational and psychological research, as indicated above, recent changes have been instigated through government policy. This has resulted in the agenda for professional development and practice becoming the concern of senior management, as opposed to lecturers or professional developers with background and expertise in these areas (Smith \& Oliver, 2000). In effect, the trend has been to move pedagogy out of the domain of professionalism and into the realm of policy.

A fundamental power shift has resulted from these changes. The traditional role of the lecturer as the authoritative source of knowledge has been eroded. The adoption of a philosophy that values the construction and critiquing of a range of perspectives on issues has placed the learner on a more equal 
footing as a discriminating consumer of opinion. In more radical revisions of the educational context, lecturers have adopted a subservient role, acting as a facilitator of students' independent learning, in marked contrast to their traditional role as a director and assessor of learning.

\section{A benchmarking tool for the locus of control}

The discussion above has highlighted several changes in the power relationships concerning pedagogy and professionalism. Based on this discussion, it is possible to devise a benchmarking tool that allows comparisons to be drawn, both between institutions and within the same institution over a period of time. This tool requires the locus of control for a series of issues to be mapped, allowing comparisons to be made. This can be achieved using the table shown below (Table 1).

Table 1: the benchmarking tool

\begin{tabular}{|l|l|l|l|}
\hline & Student & Lecturer & Management \\
\hline Choice of pedagogy & & & \\
\hline Judging lecturers' performance & & & \\
\hline Focus of learning process & & & \\
\hline Development of content & & & \\
\hline Design of syllabus & & & \\
\hline Strategic development of course & & & \\
\hline
\end{tabular}

It would be possible to extend this table, for example by considering other responsibilities of teaching staff. However, this selection of categories is sufficient to illustrate the points made above. The use of this tool will be illustrated in the next section, where it will be applied to a case study of curriculum re-development.

\section{A case study: from traditional teaching to distance learning}

An existing MBA programme became the focus of discussions between University A and a governmental initiative in another country that wanted to access distance learning courses in Business. This set in motion the development of a pilot distance course, based on the existing face-to-face offering.

The original programme involved open learning materials that were run in conjunction with traditional workshops. When the decision was made to re-develop this course in a distance learning format, the management team gave the existing tutors the task of supplementing the written text with learning technology. There were clear financial constraints in place. The management team was clearly reluctant to commit further funds to a course that was yet to generate income, and which had already received a budget for the original written materials, marketing, development and promotion of the course.

Only two out of the four members of the tutoring team had any experience with using learning technology. Consequently, the tutors agreed very quickly that it was necessary to adopt a team-based approach. If students experienced materials from different tutors, they could be quick to complain about any differences in the standards or format. A shared approach would also encourage consistency, allow economies of scale through the development and re-use of templates, and encourage the less able tutors to learn new skills from their more experienced colleagues.

In order to meet the tight deadlines, it was decided that the first two subjects to be authored would be those taught by the most experienced tutors. This would also allow the more experienced members to overcome potential problems with the technology, and to cascade their experiences through to the remaining team members six months later, when the students moved on to the next two subjects.

WebCT (WebCT, 2000) was selected as the medium for delivery for several reasons. Firstly, this package was centrally supported by University A. In addition, the institution's Learning Technologist had considerable experience of supporting staff using this tool. The cost was also a factor, as there were clear expectations from management that the only financial "recompense" would be in terms of staff time release. This made the evaluation of other technologies irrelevant. Based on this decision, a clear template was developed, including standardised icons and decisions about the scale of the development work that should 
be undertaken. This was used to produce a "taster" course featuring a selection of material from the full programme. This was made available during the two-month run up to its official launch.

However, the launch of the programme was delayed, which gave the management team the opportunity to revisit the course materials, including the WebCT site. This led to a discussion between the managers and tutors, which was started by a request for "more" to be added. The discussion made it clear that the management team had no explicit pedagogic goals in mind, although they did set a broad agenda for the development. Of primary importance was the concern that the WebCT course should be viewed as being "value for money". The question, "What do I get for my [fees] if I am a student logging on?" seemed paramount. Their pedagogic agenda focused on supplementing this text with "interactivity", although no definition or clear examples of this were given. This agenda, which is reminiscent of the self-study, drill-andpractice didactic style of teaching (cf. Gagné, 1977) stood in marked contrast to the experiential, collaborative pedagogy that the team had sought to adopt.

An additional tension arose from the management team's inspection of U.K. Open University (OU) sites. These were viewed as a standard against which the tutor's work would be judged, even though the OU's materials would have been produced by a team of experts over a period of five years. Moreover, such courses can be argued to be less, not more, time consuming in terms of both development and delivery if quality is to be maintained. Laurillard's course appraisal model (2000) suggests that converting $40 \%$ of a course's material to an online format will increase staff time by $50 \%$ during the course, and production time by $120 \%$. What was being requested was material that was superficially similar to that of the OU, but which actually embodied a radically different pedagogic model. Moreover, the additional resources required to do justice to such a development were clearly not forthcoming; this is not altogether surprising, given that "senior management underestimate the full cost of IT" (Laurillard, 2000).

Interestingly, however, in this case, management's demands were subverted by the team involved. The tutors expanded their site by extending the templates for materials to include colour co-ordination, and by adding a series of Frequently Asked Questions (FAQs), interactive bulletin board suggestions and a "hotlinks" listing. A subsequent review of the site by the management team judged this to be satisfactory, in spite of the fact that the pedagogy and teaching aims remained unchanged.

This represents a classic example of performance goals being set and monitored without a full appreciation of their implications. In this case, the management team were not in a position to devise or assess appropriate performance management criteria, yet took this role on in order to link policy with practice. This decision represented a threat to the professionalism of the tutors involved. In response, they sought to maintain their choice of pedagogy by limiting changes to the superficial elements (style, volume of material, etc.) that the management team was basing its decisions on.

The tables below use the analytical method outlined above to analyse the changes in responsibility that emerged in this case. (Tables 2 and 3)

Table 2: the traditionally-taught course

\begin{tabular}{|l|l|l|l|}
\hline & \multicolumn{1}{|c|}{ Student } & \multicolumn{1}{|c|}{ Tutor } & Management \\
\hline Choice of pedagogy & \multicolumn{1}{|c|}{ Reflects tutors' expertise } & \\
\hline Judging lecturers' performance & Student feedback forms & $\begin{array}{l}\text { Self-assessment based on } \\
\text { feedback }\end{array}$ & \\
\hline Focus of learning process & $\begin{array}{l}\text { Some student-centred } \\
\text { activities }\end{array}$ & Mainly tutor-led & \\
\hline Development of content & & Tutors' responsibility & \\
\hline Creation of presentational style & & Tutors' responsibility & \\
\hline Design of syllabus & & Tutors' responsibility & Quality audit \\
\hline Strategic development of course & & & \\
\hline
\end{tabular}


Table 3: the distance learning course

\begin{tabular}{|l|l|l|l|l|}
\hline & \multicolumn{1}{|c|}{ Student } & \multicolumn{1}{|c|}{ Tutor } & \multicolumn{1}{c|}{$\begin{array}{c}\text { Learning } \\
\text { Technologist }\end{array}$} & Management \\
\hline Choice of pedagogy & & $\begin{array}{l}\text { Subverted } \\
\text { management requests } \\
\text { to maintain own } \\
\text { model }\end{array}$ & $\begin{array}{l}\text { Specified teaching } \\
\text { via web pages, } \\
\text { attempted to } \\
\text { specify model }\end{array}$ \\
\hline Judging lecturers' performance & $\begin{array}{l}\text { Student } \\
\text { feedback } \\
\text { forms }\end{array}$ & & $\begin{array}{l}\text { Performance } \\
\text { management } \\
\text { scheme }\end{array}$ \\
\hline Focus of learning process & $\begin{array}{l}\text { Student- } \\
\text { centred }\end{array}$ & Tutor as facilitator & & \\
\hline Development of content & & Shared responsibility & $\begin{array}{l}\text { Shared } \\
\text { responsibility }\end{array}$ & \\
\hline Creation of presentational style & & Tutors' responsibility & & \\
\hline Design of syllabus & & Tutors' responsibility & & Quality audit \\
\hline Strategic development of course & & & & \\
\hline
\end{tabular}

On this revised model, shown in Table 3, the tutors only maintain sole responsibility for two activities out of seven; other areas of responsibility are either reduced or removed. Judgement about the tutors' performance during development was based on a set of criteria that were maintained in the face of criticism, although some of these were eventually by-passed by the tutors involved. The degree of control held by tutors during the delivery of the course has been reduced by giving greater autonomy to the students.

\section{An extension of the case}

Importantly, two categories that remain under the lecturers' control are also challenged by the recommendations of the Dearing report (1997). This noted the high costs of developing material, particularly for computer-based resources, and advocated the re-use of existing materials in order to improve costeffectiveness. Added to this, global competition between H.E. institutions has led to suggestions that modularisation should be increased so that potential students can create customised courses to suit their needs.

Finally, the issue of style must be considered. Many institutions are now taking an increased interest in establishing and controlling their corporate identity, and have reflected this in the adoption of templates and house styles for web-based materials. This reflects further centralisation within institutions, and if implemented in the case above would remove another creative aspect of curriculum development, namely, the creation of a format tailored to the style and content of the course.

If the model described in the case study above were to be developed along these lines, it would reduce the control of the lecturer still further, as illustrated in Table 4. (Note that a further category of stakeholder has been added here, representing the shift from internal responsibility to an outside source.)

In summary, the development of a more competitive model, driven by the market, adopting a student-centred approach and implemented under the paradigm of new managerialism would remove almost all responsibility from lecturers. This would have the effect of reducing their status to that of teaching assistants. Although such a model has not been fully implemented in the case described above, it is important to recognise that such a model represents the logical extension of the policies and contextual developments described above. 
Table 4: an extension of the course

\begin{tabular}{|c|c|c|c|c|c|}
\hline & Student & Tutor & $\begin{array}{c}\text { Learning } \\
\text { Technologist }\end{array}$ & $\begin{array}{l}\text { Content } \\
\text { Provider }\end{array}$ & Management \\
\hline Choice of pedagogy & & & & & $\begin{array}{l}\text { Specified } \\
\text { teaching via } \\
\text { web pages }\end{array}$ \\
\hline $\begin{array}{l}\text { Judging lecturers' } \\
\text { performance }\end{array}$ & $\begin{array}{l}\text { Student } \\
\text { feedback } \\
\text { forms }\end{array}$ & & & & $\begin{array}{l}\text { Performance } \\
\text { management } \\
\text { scheme }\end{array}$ \\
\hline Focus of learning process & $\begin{array}{l}\text { Student- } \\
\text { centred }\end{array}$ & $\begin{array}{l}\text { Teacher as } \\
\text { facilitator }\end{array}$ & & & \\
\hline Development of content & & & $\begin{array}{l}\text { Responsibility for } \\
\text { implementing } \\
\text { materials }\end{array}$ & $\begin{array}{l}\text { Responsible } \\
\text { for } \\
\text { development }\end{array}$ & \\
\hline $\begin{array}{l}\text { Creation of presentational } \\
\text { style }\end{array}$ & & & & & $\begin{array}{l}\text { Central house } \\
\text { style imposed }\end{array}$ \\
\hline Design of syllabus & $\begin{array}{l}\text { Students' } \\
\text { choice }\end{array}$ & & & & \\
\hline $\begin{array}{l}\text { Strategic development of } \\
\text { course }\end{array}$ & & & & Quality audit & \\
\hline
\end{tabular}

\section{Discussion of implications}

The above case clearly illustrates the disempowerment of lecturers. Most of the control has been passed to management, with smaller amounts being given to other stakeholders such as the students or Learning Technologists. However, for all of the areas of responsibility in this case, the shift in power is away from the tutors.

The effect of this is to radically alter lecturers' conception of their role, which poses a challenge to those in the profession. "Long established conceptions of roles, duties, rights and responsibilities are deconstructed in the face of resentment, resistance, low morale and scepticism. The least amenable leave or retire, the most mouldable enter at the bottom of the profession" (Ferguson, 1994). However, as the following quote illustrates, attempts to reject new managerialism at this stage would probably be naïve.

In teaching... as sceptical teachers submit to force majeure and comply with the National Curriculum programmes of study, test their pupils, accept appraisal, as reluctant heads sit on sub committees of governing bodies to apportion the schools budgets etc, they come gradually to live with and be imbued by the logic of new roles, new tasks, new functions, and in the end to absorb partial redefinitions of their professional selves. As redefinition takes hold, it is likely to be deep rooted and long lived. The greatest source of resistance will have departed, redefinitions will not be easily undone, and as young recruits who never knew anything different move up in the hierarchy, the consolidation of the new regime embeds. Once a shift in world view of this profundity takes place only an equal and opposite force will achieve a reversal.

(Ferguson, 1994, pp 113).

Other authors draw similar conclusions:

Increased emphasis of evaluation of work performance and greater role for the knowledge elite have been identified as crucial elements in the increased stratification of professions. Combined with the impact of managerialism in terms of increasing both the management components of all professional roles and the significance of managerial professionals, the direction would appear towards greater fragmentation.

(Exworth \& Halford, 1999)

Such a counter-development is unlikely to occur in the current political climate. Exworth \& Halford (1999) point to a speech by Tony Blair on the future of the NHS as being indicative of the continued implicit support of management: 
The NHS needs to be well managed, and there are many dedicated and good managers. What concerns me are the excesses of the market and not the fact we need skilled management to run the service.

In fact, Exworth \& Halford conclude from this that managerialism will be accepted as a key government strategy for implementation of local policy, even taking precedence over the influence of the market. Within H.E., this would imply increased centralisation, perhaps even at the expense of notion of the student as customer.

In terms of the three-part model illustrated in Figure 1, all this points to a clear shift in power from the individualism of professional lecturers to a collective control implemented through new managerialism.

(Figure 2)

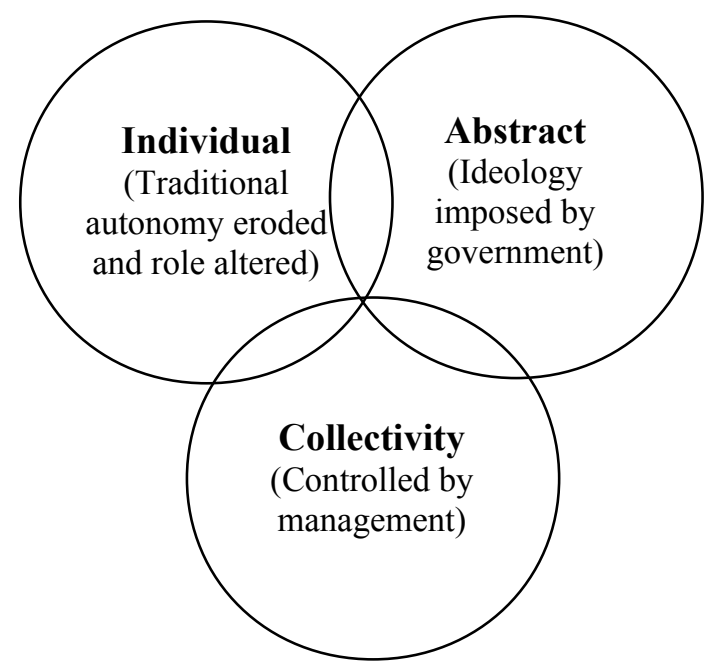

Figure 2: The shift in control resulting from the introduction of new managerialism

Interestingly, however, another governmental policy may represent a challenge to this development. The Dearing report (1997) proposed the creation of a professional body for lecturers. This is currently being implemented as the Institute for Learning and Teaching (ILT).

On the surface, this would seem to be another instance of centralisation. This is certainly one possible outcome. However, an alternative would be for the ILT to value and support the individualism of its members, adopting an emergent model of professional practice rather than a policy-driven one. Such a development would provide individual lecturers with a new rationale for their practice, based on a mutually agreed ideology that could form an alternative to the collectivity imposed by management (see Figure 3 ).

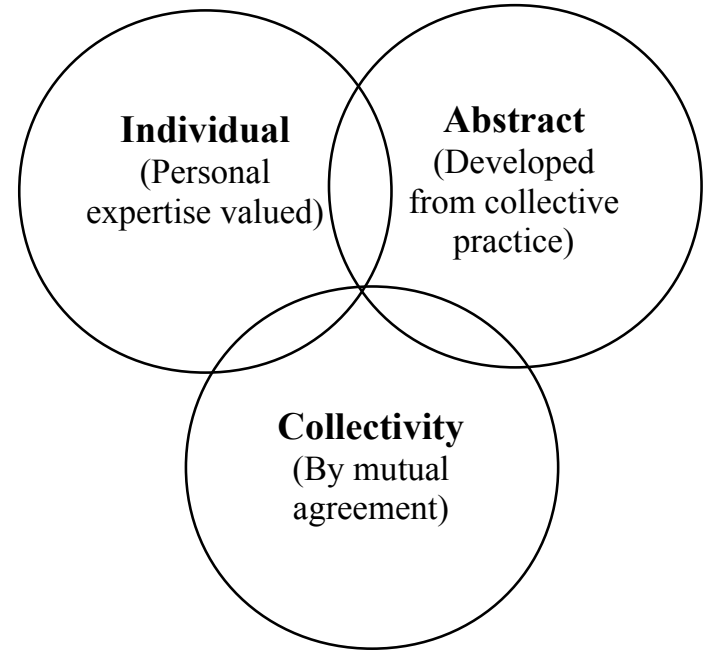

Figure 3: A potential alternative based on emergent models of professionalism 
It seems likely (at least in the short term) that both of these models will be in operation. This will, inevitably, highlight the tension in government policy between centralisation and the need for collectivity (as, for example, reflected in performance management goals) to be based on real practice and expertise.

Following on from this, one of the tasks that will need to be addressed by the ILT is to establish what practice currently means for lecturers. As illustrated in the case above, style, format and presentation are currently part of curriculum design, yet these aspects of marketing are unlikely to be something that many lecturers have any experience of. Additionally, the relative importance of professional responsibilities will need to be considered. If, for example, Dearing's recommendations about an increase in resource-based learning are implemented, then curriculum development may become as important (or more important) than teaching for many lecturers. Such changes clearly illustrate the redefinition of roles described by Ferguson, above.

In summary, then, it would seem that the influence of new managerialism is set to increase. What remains to be seen is the extent to which this can be driven by practitioners, rather than by centralised authority.

Improbable as this is in a period of political convergence, managerialism may turn out to be the most enduring legacy of the reforms. The combination of an occupational group unconfident of how far it can take its resistance without fragmenting, and a government too weakened to achieve its more radical political objectives leaves open the way for dilute reforms and creeping managerialism capable of surviving any seriously envisageable political swings. Cautious managerialism in the service of cautious centralism may emerge as a legacy of an exhausted new right to produce an educational landscape which would, nevertheless, have been unimaginable a decade ago.

(Ferguson, 1994)

\section{Conclusions}

The process of empowerment is important, but complex. Giving power to one stakeholder implicitly removes it from another. In this paper, the parallel development of new managerialism and pedagogic development has been discussed, and the impact of these on lecturers has been illustrated. New governmental priorities have caused significant changes in Higher Education, particularly in the relationship between lecturers and their managers. This has led to a marked decrease in their ability to control their practice and working environment. Moreover, the development of student-centred pedagogy, compounded by the catalytic effect of new technology, has redefined their role still further.

Consequently, traditional areas of authority have been taken away from the lecturer and given to other stakeholders. This shift has been identified through the development of simple analytical tools that map out the responsibilities of stakeholders against a range of tasks. In recognition of the changing role of lecturers, new areas of responsibility have been identified. However, it remains unclear whether these responsibilities fall within the lecturers' existing expertise, or if they represent an additional threat to autonomy by requiring widespread re-training.

Are these changes sustainable in the long term? At a superficial level, it would seem that self-directed learning should require less support from expensive experts such as lecturers - an important consideration in the current climate of decreasing resources per student (Daniel, 1998). However, a closer inspection highlights the fact that the costs are likely to be higher than many managers realise (Laurillard, 2000). Moreover, although individual contact time might be reduced, the nature of the support (addressing individuals' problems) means that this approach may well prove less efficient for large student cohorts (Conole \& Oliver, 1998).

The establishment of the ILT also poses an interesting dilemma in terms of control: will the establishment of a common professional body act as a driver for conformity, or will it give credibility to the diversity of its constituency? Clearly, this issue is yet to be resolved. However, it seems likely that the issue of who should dictate pedagogy - lecturers or managers - will be reflected in the development of the ILT. 
Empowerment is an important process, and clearly one that should remain on the agenda of managers in Higher Education. However, in this paper we have argued that the negative impact of such changes must also be recognised. In order to give power to one group, it must be taken from another; for example, in this context, the autonomy of the lecturer has been eroded as the locus of control has moved higher up a centralised administrative structure.

Consequently, we have developed tools that help this shift in power relationships to be documented and analysed. In the current context, changes in management policy and in pedagogy have combined to systematically disenfranchise lecturers, posing a serious threat to the future the profession. Unless "creeping managerialism" (Ferguson, 1994) is recognised and addressed, the lecturing profession will inevitably find itself in crisis.

\section{References}

Blalock, A. (1999) Evaluation Research and the Performance Management Movement: From Estrangement to Useful Integration? Evaluation, 5, 2, 117-149.

Clarke, C., Cochrane, A. \& McLaughlin, E. (1994) Managing Social Policy. London: Sage.

Conole, G. \& Oliver, M. (1998) A pedagogical framework for embedding C\&IT into the curriculum. ALT-J, 6, 2, 4-16.

Daniel, J. (1998) Mega-Universities and Knowledge Media: Technology Strategies for Higher Education. Stylus Publishing, LLC.

Davies, A. \& Kirkpatrick, I. (1995) Performance indicators, bureaucratic control and the decline of professional autonomy. In Kirkpatrick, I. \& Lucio, M. (Eds) The Politics of Quality in the Public sector. London: Routledge.

Dearing, R. (1997) Higher Education in the Learning Society. London: HMSO.

Exworthy, M. \& Halford, S. (1999) Professionals and the New Managerialism in the Public Sector. OU Press.

Fergusson, R. (1994) Managerialism in Education. In Clarke, C., Cochrane, A. \& McLaughlin, E. (Eds.) Managing Social Policy. London: Sage.

Gagné, R. (1977) The Conditions of Learning. New York: Holt Reinehart and Winston.

Harasim, L., Hiltz, S. R., Teles, L., \& Turoff, M. (1995) Learning Networks: A Field Guide to Teaching and Learning Online. Cambridge, MA: MIT Press.

Hoggett, M. (1991) The decline of professional autonomy. Cited in Davies \& Kirkpatrick (1995).

Hutton, W. (1995) The State We're In. Cape.

Kirkpatrick, I. \& Lucio, M. (1995) The Politics of Quality in the Public sector. London: Routledge.

Laurillard, D. (1993) Rethinking University Teaching. London: Routledge.

Laurillard, D. (2000) Educational Imperatives of the Information Age. ACM millenial lecture, 11/4/2000.

Mayer, R. (1996) Learners as information processors: legacies and limitations of educational psychology's second metaphor. Educational psychologist, 31, 3, pp. 1-19.

Newman, J. \& Clarke, J. (1994) Going about our business? The managerialisation of public services. In Clarke, C., Cochrane, A. \& McLaughlin, E. (Eds.) Managing Social Policy. London: Sage. 
Pollitt, C. (1990) Managerialism and the Public Services. Oxford: Blackwell.

Pollitt, C. (1993) Managerialism and the Public Services, Second Edition. Oxford: Blackwell.

Pollitt, C., Birchall, J. \& Putman, K. (1998) Decentralising Public Service Management. Macmillan Press.

Skinner, B. (1950) Are theories of learning necessary? Psychological review, 57, pp. 193-216.

Smith, J. \& Oliver, M. (2000) The implementation of a national framework for academic development in the use of C\&IT. EFFECTS report no. 4, University of North London.

WebCT (2000) WebCT.com: The e-Learning Hub. http://www.webct.com; URL last visited 18/4/00. 